\title{
Hypoglossal nerve stimulator placement in a child with severe refractory OSA: a novel procedure in the paediatric population
}

\author{
Clayton D Adams, ${ }^{1}$ Srijaya K Reddy 다, ${ }^{1}$ James D Phillips, ${ }^{2}$ Brian R Emerson ${ }^{1}$
}

${ }^{1}$ Department of Anesthesiology, Division of Pediatric Anesthesiology, Monroe Carell Junior Children's Hospital at Vanderbilt, Nashville, Tennessee, USA

${ }^{2}$ Department of Otolaryngology, Monroe Carell Junior Children's Hospital at Vanderbilt, Nashville, Tennessee, USA

\section{Correspondence to}

Dr Srijaya K Reddy; srijaya.k.reddy@vumc.org

Accepted 7 April 2021

Check for updates

(c) BMJ Publishing Group Limited 2021. No commercial re-use. See rights and permissions. Published by BMJ.

To cite: Adams CD,

Reddy SK, Phillips JD,

et al. BMJ Case Rep

2021;14:e242592.

doi:10.1136/bcr-2021-

242592

\section{DESCRIPTION}

Obstructive sleep apnoea (OSA) in children is primarily managed surgically with adenotonsillectomy and/or with continuous positive airway pressure (CPAP). ${ }^{1}$ Adherence to CPAP in children is generally poor due to discomfort, inconvenience or cognitive delay. The hypoglossal nerve stimulator (HNS) is a novel device that has gained popularity in treating adults with severe refractory OSA. HNS works by delivering stimulation to upper airway muscles, stiffening the tongue and soft tissues to improve breathing during sleep. ${ }^{2}$ HNS is better tolerated and less irritating than CPAP, with good long-term efficacy. Recently, HNS has been trialled in children with refractory OSA with positive outcomes. $^{12}$

A child with Down syndrome and severe refractory OSA (Apnoea-Hypopnoea Index, or AHI, of 45 after adenotonsillectomy) with CPAP noncompliance presented for HNS implantation. After routine mask induction and intravenous placement, oxymetazoline was sprayed in each nostril. He was nasotracheally intubated via direct laryngoscopy with a $6.5 \mathrm{~mm}$ nasal Ring-Adair-Elwyn (RAE tube, with the neck maintained in neutral position. No muscle relaxants were administered due to the need for intraoperative nerve monitoring. The operating room bed was rotated 90 degrees and a shoulder roll was placed. Electrodes were placed in the genioglossus and styloglossus muscles by the surgeon for nerve monitoring. Surgical dissection was performed through a submandibular incision, isolating the hypoglossal nerve (figure 1), and the stimulating electrode was inserted. A pleural respiration sensor was placed through a second incision in the right lower chest with dissection down to the fourth intercostal space (figure 2). Hypoglossal electrode and respiration sensor leads were connected to an implantable pulse generator in the right subclavicular space. The patient received a total of $25 \mathrm{~mL} / \mathrm{kg}$ crystalloid, $1 \mathrm{mcg} / \mathrm{kg}$ fentanyl and $0.01 \mathrm{mg} / \mathrm{kg}$ hydromorphone throughout the 5 -hour case. He was extubated awake at the end of surgery and weaned to room air in the recovery room. He was admitted overnight for observation and discharged home without any complications or additional interventions. Further recovery at home was uneventful, and during outpatient follow-up, the patient had subjective improvement in his symptoms, as well as a decrease in his AHI to 12 . He has been compliant with the device, using the implant approximately 70 hours per week.

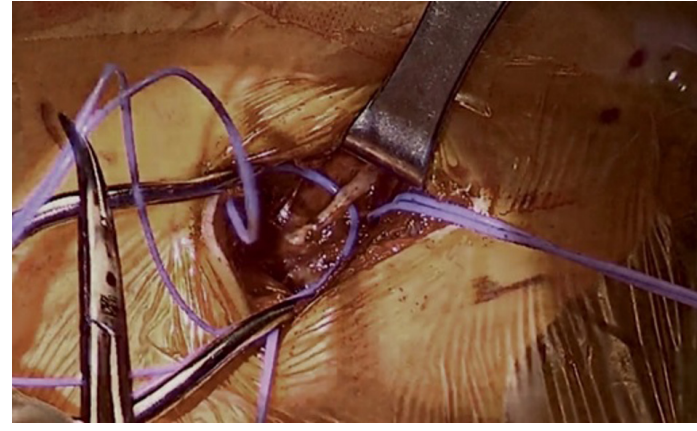

Figure 1 Hypoglossal nerve isolation in a child with severe refractory obstructive sleep apnoea.

As a result of technological advancements, HNS has been introduced as a novel technique to manage severe refractory OSA. Due to its success in adults, HNS is now being extended to the paediatric population with persistent severe OSA after adenotonsillectomy or with poor CPAP compliance. Down syndrome is a common genetic disorder in which severe OSA often exists (prevalence of 55\%-80\%) due to hallmark anatomical features. ${ }^{13}$ Adenotonsillectomy only resolves OSA in 16\%-33\% of patients with Down syndrome. ${ }^{1}$ Additionally, intellectual disability associated with Down syndrome leads to

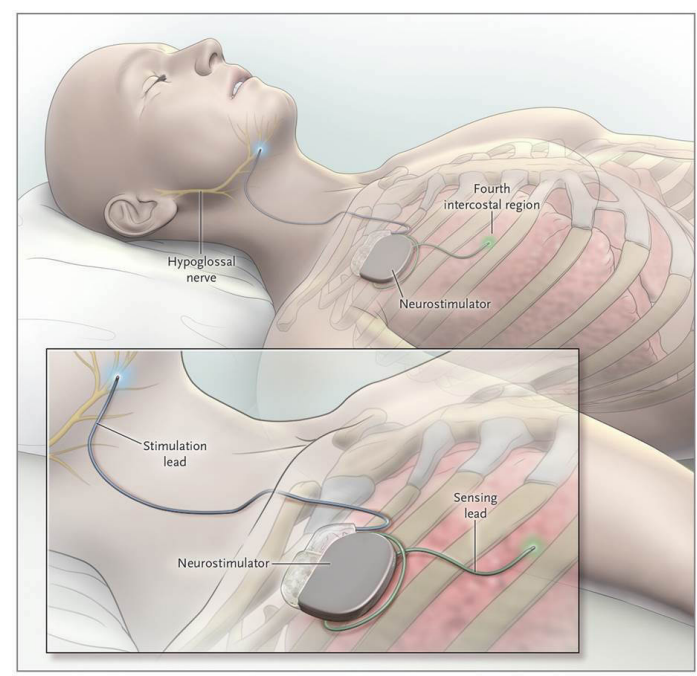

Figure 2 Hypoglossal nerve stimulator placement. (From The New England Journal of Medicine, Strollo PJ et al, Upper-airway stimulation for obstructive sleep apnea, 370(2):139-49. Copyright 2014 Massachusetts Medical Society. Reprinted with permission from Massachusetts Medical Society.) 


\section{Learning points}

Challenges in managing severe obstructive sleep apnoea (OSA) in children include pathology refractory to adenotonsillectomy and intolerance of continuous positive airway pressure.

- Hypoglossal nerve stimulators are novel devices that are implanted under general anaesthesia that deliver stimulation to upper airway muscles to improve breathing during sleep.

- Recent evidence suggests these devices are well tolerated and can be effective in reducing sleep apnoea severity in paediatric patients with refractory OSA.

low adherence to CPAP. HNS is a promising device in this unique population, with early data demonstrating good tolerance and reduced AHI scores. Although HNS has only been trialled in a small number of paediatric patients, with continued efficacy it will likely become a standard treatment in refractory OSA.
Contributors CDA, SKR and BRE drafted the initial manuscript. JDP provided the image for the manuscript. All authors were involved with editing and approval of the final manuscript.

Funding The authors have not declared a specific grant for this research from any funding agency in the public, commercial or not-for-profit sectors.

Competing interests None declared.

Patient consent for publication Parental/guardian consent obtained.

Provenance and peer review Not commissioned; externally peer reviewed.

\section{ORCID iD}

Srijaya K Reddy http://orcid.org/0000-0002-1924-8976

\section{REFERENCES}

1 Caloway CL, Diercks GR, Keamy D, et al. Update on hypoglossal nerve stimulation in children with Down syndrome and obstructive sleep apnea. Laryngoscope 2020;130:E263-7.

2 Certal VF, Zaghi S, Riaz M, et al. Hypoglossal nerve stimulation in the treatment of obstructive sleep apnea: a systematic review and meta-analysis. Laryngoscope 2015;125:1254-64.

3 Trucco F, Chatwin M, Semple T, et al. Sleep disordered breathing and ventilatory support in children with Down syndrome. Pediatr Pulmonol 2018;53:1414-21.

Copyright 2021 BMJ Publishing Group. All rights reserved. For permission to reuse any of this content visit

https://www.bmj.com/company/products-services/rights-and-licensing/permissions/

BMJ Case Report Fellows may re-use this article for personal use and teaching without any further permission.

Become a Fellow of BMJ Case Reports today and you can:

- Submit as many cases as you like

- Enjoy fast sympathetic peer review and rapid publication of accepted articles

- Access all the published articles

Re-use any of the published material for personal use and teaching without further permission

\section{Customer Service}

If you have any further queries about your subscription, please contact our customer services team on +44 (0) 2071111105 or via email at support@bmj.com.

Visit casereports.bmj.com for more articles like this and to become a Fellow 